\author{
젖소에 있어서 원유 중 체세포수, 스트레스 및 면역물질에 대한 \\ 환경효과와 유전모수 추정 \\ 안병석 · 서국현 · 권응기 \\ 농촌진흥청 축산연구소
}

\title{
Estimation of Environmental Effects and Genetic Parameters for Somatic Cell Score, Stress and Immunological Traits in Holstein Cattle
}

\author{
B. S. Ahn, G. H. Suh and E. G. Kwon \\ National Livestock Research Institute, RDA.
}

\begin{abstract}
Milk yield and its quality traits determine the dairy enterprise profitability and sustainability. Milk quality traits including somatic cell counts (SCC) is an upcoming economic challenge for dairy farming community in Korea. This study estimated the effect of parity, stage of lactation (early, mid and late lactation) on SCC, stress (blood cortisol) and immunity (blood IgG, lymphocyte and neutrophil) traits, their heritabilities and genetic correlations between them. SCS and blood neutrophil count were significantly affected by both parity and stage of lactation, however; IgG was affected by only stage of lactation, and blood cortisol and lymphocyte were not affected by both factors. The SCS has shown increasing trend with the parity, however; the difference between first and second parity, second and third parity were not significant. The SCS in early ( $\leq 90$ days) and late lactation $(181 \leq$ days) were higher than that of mid lactation (91 180 days). Cortisol concentration in blood was lowest in fourth parity, however; the differences among the first three parties were not significant. The IgG was higher in fourth parity compare with first parity however; all other comparisons were noted non-significant. The IgG concentration was significantly higher in early lactation than those of mid and late lactation. The blood lymphocytes were decreased with increasing parity however the differences beyond second parity were not significant. The neutrophils were increased with the increasing lactation stage however; the difference between early and mid lactation was not significant. Although heritability of SCS was still lower, but it was meaningful value (0.09) and may be considered to improve milk quality. The genetic correlations between SCS and cortisol (-0.96), and lymphocyte (-0.76) were highly negative. Heritability of cortisol was low, however genetic correlations between cortisol and lymphocyte (0.79) was highly positive. IgG with medium heritability was correlated negatively with lymphocyte $(-0.88)$ and neutrophil (-0.98). Lymphocyte was lowly heritable and highly correlated with neutrophil concentration (0.87).

This study suggested that cortisol, IgG, lymphocyte and neutrophil being positively genetically correlation with somatic cell score could be used as alternative traits to enhance milk quality in Holstein cattle. Further studies are warranted to estimate genetic relationships between immunological and production traits to increase the genetic merit of Holstein cows for milk yield, to improve animal health and economic viability under intensive management system.
\end{abstract}

(Key words: Genetic parameters, SCS, Cortisol, Lymphocyte, Neutrophil)

Corresponding author : Byeong Seog Ahn, National Livestock Research Institute, R.D.A.

\# 9 Oryong-ni Seongwhan-eup Cheonan-si Chungnam, 330-801. Korea

Tel : 041-580-3392 Fax : 041-580-3419 E-mail : abs3382@rda.go.kr 


\section{I. 서 론}

농가에서 생산되는 유량에 대하여 쿼터제가 적용됨에 따라 유량 증산에 의한 소득 향상에 는 여러 가지 제약이 따른다. 반면에, 원유품질 이 농가소득 향상에 크게 영향을 미치게 되었 고 이를 위하여 많은 노력과 주의를 기울이고 있다. 그러나 2005년 6월 현재, 목장에서 생산 한 원유의 위생등급에 대하여 세균수를 기준으 로 할 때 1 등급이 $83.0 \%$, 체세포수를 기준으로 할 때 1 등급이 $45.2 \%$ 로 나타났다(월간 낙농. 육우 9월호, 사단법인 한국낙농육우협회). 이 결과로 볼 때 많은 노력을 기울여 유질을 개선 하고 있음에도 불구하고 체세포수에 의한 1 등 급은 절반수준에도 못 미치고 있어 원유품질 향상을 위한 노력이 지속적으로 수행되어야 할 것으로 생각된다. 지금까지 우유의 품질을 개선 하기 위하여 사료첨가제, 착유관리, 젖소의 위 생관리 등 많은 기술들이 개발되어 왔다. 최근 에는 특정세균에 대한 유방염 백신 개발, 유방 염 발생이 적은 젖소의 호중구와 백혈구에 대 한 특성 연구, 고능력우와 저능력우간의 체세 포수와 유량에 대한 대사산물의 차이, 분자 유 전학 측면에서 유방염 발생 인자 구명 등이 수 행되었으나(Kulberg 등, 2002; 안 등, 2005) 여 전히 해결되지 않은 부분이 많음은 잘 아는 바 와 같다. 농장에서 생산된 원유 품질에 가장 큰 영향을 미치는 체세포수는 유선조직이 세 균으로부터 감염되었거나 조직의 세포들이 노 쇠 탈락되어 우유 중에 포함된 결과라고 할 수 있으므로 세균감염에 대한 젖소의 면역기능의 향상이 중요하다고 생각된다. Detilleux 등(1995) 은 홀스타인 젖소의 면역기능장애로서 분만 전 2 3주에서 분만 후 3 주까지 호중구의 기능 이 억제되고, 특히 보통 젖소에 비하여 고능력 젖소에서는 순환호중구(circulating neutrophils)와 단핵구(mononuclear cell)의 수가 유의적으로 많 았다고 하였다. 면역물질은 유량 생산에 대한 부작용 없이 가축 본래의 면역능력을 선발할 수 있음으로 정상적인 환경하에서 질병에 강한 개체를 관찰하거나 또는 직접 선발하는 방법, 특정 질병에 대한 자손과 자매를 통한 간접선 발 등이 이용된다(Detilleux 등, 1994). 사육규모 가 커지고 밀집 사육됨에 따라 내병성 육종이
강력히 요구되지만 개발도상국에서는 경비도 많이 들뿐만 아니라 백신 개발이 어렵고 효과 적이지도 못하기 때문에 내병성 개체의 선발이 더욱 중요하다(Detilleux 등, 1994). 이리하여 유 방염에 대한 저항성이 큰 젖소의 선발이 중요 하지만 유방염과 면역에 관련된 유전적 특성을 연구한 결과는 많지 않고 또한 찾기가 쉽지 않 았다. 따라서 본 연구에서는 유방염과 관련이 깊은 체세포수, 스트레스와 관계가 있는 코티 솔, 면역과 연관된 immunoglobulin $\mathrm{G}$, 림프구 및 호중구의 유전특성을 분석 함으로서 젖소의 유방염 저항성 및 우유의 품질 개선에 필요한 기초 자료를 얻고자 실시하였다.

\section{ㅍ. 재료 및 방법}

본 시험을 위하여 이용된 젖소는 축산연구소 에서 사육하고 있는 착유우로서 사사 관리를 하였고 연중 TMR 사양에 의한 평균 12 시간의 착유간격을 가지는 우군에서 자료를 수집하고 시료를 채취 분석하였다. 대사물질과 체세포수 는 안 등(2005)과 같이 조사하여 분석하였다. 즉, 우유 시료는 오전 착유와 오후 착유시 시 료를 채취하였으며 체세포수와 우유내 요소태 질소 (Milk Urea Nitrogen, MUN)은 Somascope MK2/Lactoscope FTIR으로 분석하였고 체세포수 는 로그함수로 변환하였다 $\left(\mathrm{SCS}=\log _{2}(\mathrm{scc} \times 1000 /\right.$ $100000)+3)$. 혈액은 소의 경정맥에서 일회용주 사기로 채취하여 항응고제인 EDTA-2K가 들어 있는 멸균 진공관과 항응고제가 첨가되지 않은 멸균진공관에 넣어 실험실로 가져왔으며 혈청 은 멸균진공관의 혈액이 굳은 다음 실온에서 원 심분리 $(2000 \times \mathrm{g}, 15$ 분 $)$ 하여 상층액을 회수 후 냉 동보관 하였으며 혈액학치는 Automatic Blood Cell Counter (System 9018, Serono, Switzerland) 로 분석하였고, 혈액화학치는 보관중인 혈청을 이용 Blood Chemistry Analyzer (Express-plus 550, Ciba corning, USA)로 분석하였다.

통계분석을 위하여 산차효과로서 4산차 이 상은 4산차 같이 간주하였으며 산차별 공시 두수는 $1,2,3,4$ 산차별로 각각 $98,68,37$, 36두 이었으며 비유기는 편의상 3개의 비유기 즉, 초기(90일 이하), 중기(91 180일), 후기(180 일 이상)로 구분하였는데 유기별 두수의 분포 
는 각각 $52,58,129$ 두 이었다. 조사된 형질에 대한 분만산차와 비유기가 미치는 효과는 SAS 9.1를 이용하여 $y_{i j k}=\mu+P_{i}+D_{j}+e_{i j k}$ 와 같은 모형식으로 추정하였고, 이들 형질 에 대한 유전력과 유전상관을 추정하기 위하 여 VCE-5 (Kovac 과 Groeneveld, 2003)를 이용 하였으며 그 모형은 $y_{i j k l}=\mu+A_{i}+P_{j}+D_{k}+$ $e_{i j k l}$ 와 같다. 여기서 $y_{i j k(l)}$ 은 관측치, $\mu$ 는 평균, $A_{i}$ 는 $\left(0, A \sigma_{a}^{2}\right)$ 의 분산을 가지는 개체의 임의 효과이며 분산 $A$ 는 개체의 혈연계수 행렬, $P_{j}$ 는 산차로서 고정효과 $(j=1 . .4)$ 이며, $D_{j}$ 도 비유 기로서 고정효과 $(j=1,2,3)$ 이고, $e_{i j k(l)}$ 은 나머 지의 임의효과로 간주하였다. 또한 표현형 상 관은 SAS 9.1를 이용하여 구하였다.

\section{III. 결과 및 고찰}

공시된 홀스타인 젖소의 우유 중 체세포수, 스트레스와 관련이 있는 코티솔, 면역물질인 IgG, 림프구, 호중구에 대한 분석결과를 Table 1에 제시하였다. 체세포수와 코티솔, 림프구는 변이의 정도가 크게 나타났으나 면역물질인 IgG 와 중성구는 상대적으로 변이가 작았다. Abeni 등(2005)에 의하면 코티솔의 수준은 착유실마다 다르다고 하였는데 일반 착유실에서는 $0.31 \mu \mathrm{g}$ /dL이었으며, 자동착유기(automatic milking system)
에서는 $0.63 \mu \mathrm{g} / \mathrm{dL}$ 의 범위를 나타낸다고 하여 본 연구에서도 비슷한 결과를 얻었지만 변이의 정도를 고려할 때 동일한 환경에서도 스트레스 에 반응하는 개체간의 정도는 심한 것으로 추 정되었는 바 이와 관련하여 더 많은 연구가 필 요할 것으로 사료된다. 또한 $\operatorname{Smith(2002)ㅇㅔ~ㄸㅏ~}$ 르면 림프구의 범위는 $2.3 \sim 9.3 \times 10^{3} / \mathrm{uL}$ 이라고 하여 본 연구 결과는 정상적인 범위에 있었다 고 할 수 있으며, IgG와 호중구는 안 등(2005) 의 보고와 비슷하였다.

한편, 이들 형질에 대한 산차와 비유기의 효 과를 추정한 결과는 Table 2에 제시하였는데, 체세포수와 호중구에 대하여 분만 산차는 영향 을 미치는 것으로 나타났고 $(\mathrm{p}<0.01)$, 비유기에 있어서는 체세포수와 IgG, 호중구가 영향을 받 는 것으로 나타났다. 그러나, 스트레스와 관련 이 있는 코티솔은 영향을 받지 않았고 림프구 도 영향이 없었는데 이는 시험을 위하여 특별 히 스트레스를 가한 것이 아니고 일상적인 우 군관리에서 조사되었기 때문이라고 생각된다. 물론 본 연구에서 제시된 성적은 일상적인 관 리를 하는 현장에서 조사되었기 때문에 통제가 잘된 특정 시험장소에서 시험축을 공시하여 스 트레스를 가한 후에 조사된 성적과는 다소 차 이가 있을 것으로 생각되나 환경요인의 분석과 각 조사 형질간의 유전특성을 추정하고 파악하

Table 1. Number of heads, overall means and standard errors for somatic cell score, stress and immunological traits

\begin{tabular}{lccccc}
\hline Source & $\mathrm{SCS}^{1)}$ & $\begin{array}{c}\text { Cortisol } \\
(\mu \mathrm{g} / \mathrm{dL})\end{array}$ & $\begin{array}{c}\mathrm{IgG}^{2)} \\
(\mathrm{mg} / \mathrm{mL})\end{array}$ & $\begin{array}{c}\text { Lymphocyte } \\
\left(10^{3} / \mathrm{uL}\right)\end{array}$ & $\begin{array}{c}\text { Neutrophil } \\
\left(10^{3} / \mathrm{uL}\right)\end{array}$ \\
\hline \hline Heads & 228 & 179 & 184 & 229 & 231 \\
\hline Overall mean & $3.78 \pm 1.92$ & $0.41 \pm 0.30$ & $30.23 \pm 6.63$ & $4.77 \pm 2.47$ & $4.21 \pm 1.52$ \\
\hline C.V. (\%) & 50.7 & 73.1 & 21.9 & 51.7 & 36.1 \\
\hline 1) ; somatic cell score, ${ }^{2)}$; immunoglobulin G. & & &
\end{tabular}

Table 2. Means squares of somatic cell score, cortisol, and immunological traits by parity and stage of lactation

\begin{tabular}{lrccccc}
\hline \multirow{2}{*}{ Source } & \multirow{2}{*}{ df } & \multicolumn{5}{c}{ Mean squares } \\
\cline { 3 - 6 } & & SCS $^{1)}$ & Cortisol & IgG $^{2)}$ & Lymphocyte & Neutrophil \\
\hline \hline Parity & 3 & $20.36^{* *}$ & $0.22^{\dagger}$ & $91.8^{\dagger}$ & 11.50 & $9.32^{* *}$ \\
Stage of lactation & 2 & $23.37^{* *}$ & 0.05 & $176.5^{* *}$ & 4.92 & $7.10^{*}$ \\
Error & 222 & 3.33 & 0.09 & 41.77 & 6.02 & 2.13 \\
& 22 & $(173)^{\Omega}$ & $(178)^{\Omega}$ & $(223)^{\Omega}$ & $(225)^{\Omega}$ \\
\hline
\end{tabular}

${ }^{1)}$; somatic cell score, ${ }^{2)}$; immunoglobulin $\left.\mathrm{G},{ }^{* *} ; \mathrm{p}<0.01,{ }^{*} ; \mathrm{p}<0.05,{ }^{\dagger} ; \mathrm{p}<0.1,.\right]$; degree of freedom. 
는 데는 문제가 없을 것으로 생각된다.

이들 형질에 대하여 산차별, 유기별로 비교 한 결과는 Table 3에 제시하였다. 체세포수는 $1,2,3$ 산차간에는 차이가 없었으나 4산차 이 상에서는 높아지는 경향이 있어 3산차 이하와 비교 할 시에 유의적인 차이가 있었고 유기별 비교에서는 비유초기(90일 미만)와 비유후기 (181일 이후)가 비유중기(91 180) 보다 높게 나타났다. 따라서 산차가 많거나 비유 초기와 비유 후기에는 체세포 관리에 주의할 필요가 있음을 확인시키는 결과라고 생각된다. 코티솔 은 체세포수의 산차 성적과 마찬가지로 3산차 이하와 4산차 이상 간에 차이가 있었고 비유기 별 성적에서는 높아지는 것처럼 보이나 차이는 없었다. 코티솔이 스트레스를 나타내는 지표로 활용되고 있음(Kulberg 등, 2002)을 감안하면 산차가 오래 될수록 주어진 환경에 적응하는 능력이 클 것으로 추정되며 4산차 이상의 젖소 에서 코티솔의 함량이 제일 낮아졌다고 생각된 다. 그러나 4산차 이상에서 체세포수는 오히려 높은 결과를 보였는데 이는 일반적으로 산차와 연령이 증가할수록 호중구, 림프구, 백혈구가
감소하고 유방염 발생은 증가하는 사실과 일치 하는 결과이었다. 한편, 코티솔의 수준은 스트 레스를 받는 축종에 따라 다양하게 관찰되며, 비록 같은 수준의 코티솔을 가지고 있더라도 투쟁 또는 우열에서 그 서열이 높은 개체는 같 은 수준의 스트레스를 받더라도 서열이 낮은 개체에 비하여 두려움을 적게 느낀다고 하였다 (Kulberg 등, 2002).

한편, 면역물질인 $\mathrm{IgG}$ 는 산차 증가와 함께 증가하는 경향을 보여 1산차와 4산차 이상의 비교에서만 차이가 있었고 유기에서는 비유 초 기가 비유 중기와 후기에 비하여 높은 결과를 보였다. 림프구는 1 산차와 4산차 이상 간에 차 이가 있었으나 유기간에는 차이가 없었다. 호 중구는 산차가 증가할수록 감소하는 경향으로 2 산차 이하와 3 산차 이상간에 차이가 있었으며 비유중기 까지는 차이가 없었고 비유 후기에는 높게 나타났다. 이상과 같은 특징을 가지는 시 험축에 대한 조사 항목에 대하여 유전 특성을 추정한 결과를 Table 4에 제시하였다. 체세포수 의 유전력은 최 등(1999)의 결과(0.03)에 비하여 비교적 높게 추정되었고, 체세포수와 림프구는

Table 3. Least square means and standard errors of somatic cell scores, stress and immunological traits by parity and stage of lactation

\begin{tabular}{|c|c|c|c|c|c|c|}
\hline \multirow[b]{2}{*}{ Source } & & \multicolumn{5}{|c|}{ Least square means and standard errors } \\
\hline & & SCS $^{1)}$ & $\begin{array}{l}\text { Cortisol } \\
(\mu \mathrm{g} / \mathrm{dL}) \\
\end{array}$ & $\begin{array}{c}\mathrm{IgG}^{2)} \\
(\mathrm{mg} / \mathrm{mL}) \\
\end{array}$ & $\begin{array}{c}\text { Lymphocyte } \\
\left(10^{3} / \mathrm{uL}\right)\end{array}$ & $\begin{array}{c}\text { Neutrophil } \\
\left(10^{3} / \mathrm{uL}\right)\end{array}$ \\
\hline \multirow{4}{*}{ Parity } & 1 & $3.31^{\mathrm{a}} \pm 0.20$ & $0.44^{\mathrm{a}} \pm 0.03$ & $28.96^{\mathrm{a}} \pm 0.84$ & $5.06^{\mathrm{a}} \pm 0.26$ & $4.31^{\mathrm{a}} \pm 0.15$ \\
\hline & 2 & $3.60^{\mathrm{ab}} \pm 0.24$ & $0.42^{\mathrm{a}} \pm 0.04$ & $30.43^{\mathrm{ab}} \pm 0.88$ & $4.72^{\mathrm{ab}} \pm 0.32$ & $4.32^{\mathrm{a}} \pm 0.19$ \\
\hline & 3 & $3.99^{\mathrm{b}} \pm 0.30$ & $0.45^{\mathrm{a}} \pm 0.05$ & $30.54^{\mathrm{ab}} \pm 1.11$ & $4.03^{\mathrm{b}} \pm 0.41$ & $3.90^{\mathrm{b}} \pm 0.24$ \\
\hline & $4 \leq$ & $4.85^{\mathrm{C}} \pm 0.30$ & $0.27^{\mathrm{b}} \pm 0.05$ & $32.66^{\mathrm{b}} \pm 1.18$ & $4.18^{\mathrm{b}} \pm 0.42$ & $3.32^{\mathrm{b}} \pm 0.25$ \\
\hline \multirow{3}{*}{$\begin{array}{l}\text { Stage of } \\
\text { lactation }\end{array}$} & $\leq 90$ & $4.51^{\mathrm{a}} \pm 0.25$ & $0.37^{\mathrm{a}} \pm 0.04$ & $32.66^{\mathrm{a}} \pm 0.94$ & $4.39^{\mathrm{a}} \pm 0.36$ & $3.71^{\mathrm{a}} \pm 0.21$ \\
\hline & $91 \sim 180$ & $3.21^{\mathrm{b}} \pm 0.25$ & $0.38^{\mathrm{a}} \pm 0.04$ & $28.92^{\mathrm{b}} \pm 0.88$ & $4.31^{\mathrm{a}} \pm 0.32$ & $3.87^{\mathrm{a}} \pm 0.19$ \\
\hline & $181 \leq$ & $4.09^{\mathrm{a}} \pm 0.18$ & $0.43^{\mathrm{a}} \pm 0.03$ & $30.36^{\mathrm{b}} \pm 0.77$ & $4.78^{\mathrm{a}} \pm 0.24$ & $4.30^{\mathrm{b}} \pm 0.14$ \\
\hline
\end{tabular}

${ }^{1)}$; somatic cell score, ${ }^{2)}$; immunoglobulin G. Different superscripts in same column mean significantly different.

Table 4. Heritabilities and correlations between somatic cell score, stress and immunological traits

\begin{tabular}{ccccc}
\hline SCS $^{1)}$ & Cortisol & IgG $^{2)}$ & Lymphocyte & \multicolumn{1}{c}{ Neutrophil } \\
\hline \hline $0.09 \pm 0.06$ & $-0.96 \pm 0.17$ & $0.43 \pm 0.46$ & $-0.76 \pm 0.33$ & $-0.36 \pm 0.70$ \\
-0.11 & $0.13 \pm 0.11$ & $-0.42 \pm 0.59$ & $0.79 \pm 0.30$ & $0.40 \pm 0.54$ \\
0.26 & -0.17 & $0.27 \pm 0.12$ & $-0.88 \pm 0.16$ & $-0.98 \pm 0.08$ \\
-0.08 & 0.19 & -0.30 & $0.53 \pm 0.12$ & $0.87 \pm 0.21$ \\
0.09 & 0.21 & -0.10 & 0.75 & $0.10 \pm 0.07$ \\
\hline
\end{tabular}

${ }^{1)}$; Somatic Cell Score, ${ }^{2)}$; immunoglobulin G. Diagonal; heritabilities, upper diagonal; genetic correlation, lower diagonal; phenotypic correlation. 
높은 부의 유전상관을 보였다. 일반적으로 체 세포는 년령이 증가할수록 증가하는 경향을 나 타내지만 림프구의 수는 감소하는데 (서 등, 2005) 체세포수와 림프구간의 부의 상관은 이 러한 것을 뒷받침하는 결과라고 사료된다. 또 한 체세포수와 코티솔에서도 부의 유전상관을 나타내었는데 이는 스트레스를 받으면 체세포 수가 증가하는 것으로 알려진 보고(Burton 과 Erskine, 2003; Burton 등, 2005)와 상반되는 결 과를 보였다. 이와 같은 결과는 본 연구에 공 시된 젖소들이 스트레스를 받는 환경에서 사육 되지 않았을 뿐만 아니라 이미 일상적인 환경 에 적응되어 사육되고 있었음(Table 1)을 보여 주는 것이라고 생각하나 더 많은 연구가 필요 하다고 생각한다. 한편, 체세포수(SCS)와 림프 구는 부의 유전상관을 보였으나 호중구와는 큰 의미가 없었다. 신 등(1996)에 의하면 체세포수 (SCC)가 증가하면 호중구는 증가하지만 림프구 는 감소하였다고 하였으며, 손 등(1995)은 유방 염 원인균에 의하여 생산되는 내독소(endotoxin) 가 순환하고 있는 호중구를 파괴하거나 격리시 킴으로 혈액내 호중구의 이동을 촉진하여 백혈 구 감소가 일어난다고 하여 본 결과와 비슷하 였다. 코티솔의 유전력은 높지 않았지만 림프 구와 정의 상관을 보였고 IgG, 호중구와는 큰 의미가 없었다. 본 연구 결과로 미루어 볼 때 스트레스(cortisol)가 오히려 림프구를 증가시켜 상대적으로 세균의 침입을 억제한 것으로 생각 하지만 이들간의 기작(mechanism)에 관한 연구 가 필요할 것으로 사료된다. 한편 Chang 등 (1996)에 의하면 코티솔은 림프구 증식에 다양 하게 작용한다고 하였는바 본 연구 결과와 비 슷하였다. 한편 코티솔에 반응하는 호중구의 복잡한 기능 중 하나는 스트레스를 받는 동안 건강과 질병이라는 미묘한 균형을 깨뜨리는 역 할을 할 수도 있다고 하였다(Burton 등, 2005). 또한 코티솔과 림프구, 호중구간에서는 정의 상관관계를 보였는데 이는 Kulberg 등(2002)과 양 등(1996)에 의하면 코티솔은 호중구와 유의 적 정의 상관관계를 가진다고 보고한 성적과 일치하는 결과이다. 한편, 중 정도의 유전력을 보인 IgG는 림프구 및 호중구와는 높은 부의 유전상관을 보였는데 이는 Table 3에서 보는 바와 같이 연령(산차) 증가에 따른 IgG의 증가
와 호중구와 림프구의 감소가 이를 뒷받침하고 있다고 생각되며 서 등 (2005)도 연령이 증가할 수록 림프구는 감소한다고 보고한 바 있다. 또 한 림프구는 호중구와 유전적으로 높은 상관을 보였는데 이는 항체를 많이 함유하고 있는 림 프구와 세균에 대한 탐식작용이 큰 호중구의 작용으로 인하여 상관이 높다고 생각된다.

이상의 연구 결과로 미루어 볼 때 스트레스 정도를 나타내는 코티솔이 체세포수와 밀접한 상관 관계를 가지고 있음을 알 수 있으며 IgG 도 림프구와 호중구와 높은 상관이 있음을 알 수 있었다. 가축의 능력이 향상될수록 질병 저 항성도 영향을 받을 것으로 생각되므로 생산성 뿐만 아니라 질병 저항성을 동시에 고려하는 연구가 더욱 필요할 것이라고 생각된다.

\section{IV. 요 약}

본 시험은 유질에 영향을 미치는 체세포수에 대하여 영향을 미칠 것으로 생각되는 면역물질 에 대한 환경효과와 유전모수를 추정하고자 축 산연구소에서 사육하고 있는 착유우를 공시하 여 이들의 혈액과 우유 시료를 채취하여 조사 분석하였다. 분만산차는 체세포수와 호중구에 영향을 미치는 것으로 나타났고 $(\mathrm{p}<0.01)$, 비유 기는 체세포수와 IgG, 호중구에 영향을 미치는 것으로 나타났다. 하지만 코티솔과 림프구는 산차와 유기에 의하여 영향을 받지 않는 것으 로 나타났다. 체세포수의 산차간 비교에서 1 , 2, 3 산차간에는 차이가 없었으나 4산차 이상 에서는 높아지는 경향이 있어 3산차 이하와 비 교 할 시에 유의적인 차이가 있었고 유기별 비 교에서는 비유초기(90일 이하)와 비유후기(181 일 이후)가 비유중기(91 180) 보다 높게 나타 났다. 코티솔은 체세포수의 산차 성적과 마찬 가지로 3산차 이하와 4산차 이상 간에 차이가 있었고 비유기별 성적에서는 높아지는 것처럼 보이나 차이는 없었다. 면역물질인 IgG는 1산 차와 4산차 이상의 비교에서만 차이가 있었고 유기에서는 비유 초기가 비유 중기와 후기에 비하여 높은 결과를 보였고 림프구는 1 산차와 4산차 이상 간에 차이가 있었으나 유기간에는 차이가 없었다. 호중구는 산차가 증가할수록 감소하는 경향으로 2산차 이하와 3산차 이상간 
에 차이가 있었으며 비유중기 까지는 차이가 없었고 비유 후기에는 높게 나타났다. 체세포 수의 유전력은 낮은 수준이지만 유질 개량을 위하여 의미 있을 정도로 높게 추정되었으며 코티솔, 림프구와 부의 높은 유전상관을 보였 다. 코티솔의 유전력은 비교적 낮은 수준이었 고 림프구, 호중구간의 정의 상관관계를 보였 다. IgG의 유전력은 중 정도를 보였으며 림프 구와 호중구와는 높은 부의 유전상관을 보였 다. 림프구는 높은 유전력을 보였고 호중구와 도 높은 유전적 상관을 보였다. 호중구는 체세 포수와 비슷한 수준의 유전력을 나타내었다. 이상의 연구 결과에서 코티솔, IgG, 림프구, 호 중구가 체세포수와 유전적으로 높은 상관관계 를 가지고 있어 우유 품질 개선에 중요한 형질 임을 알 수 있었다. 또한 농가의 사육규모가 증가하고 두 당 생산성이 더욱 증가함에 따라 생산성과 질병을 동시에 고려하는 젖소개량 관 련 연구가 수행되어야 할 것으로 사료된다.

\section{$\mathrm{V}$. 인 용 문 헌}

1. Abeni, F., Calamari, L., Calza, F., Speroni, M., Bertoni, G. and Pirlo, G. 2005. Welfare assessment based on metabolic and endocrine aspects in primiparous cows milked in a parlor or with an automatic milking system. J. Dairy Sci. 88:3542-3552.

2. Burton, J. L. and Erskine, R. J. 2003. Mastitis and immunity: some new ideas for an old disease. Vet. Cli. N. Am. Food Anim. Pract. 19.1-45.

3. Burton, J. L., Madsen, S. A., Chang, L., Weber, P. S. D., Buckham, K. R., van Dorp, R., Hickey, M. and Earley, B. 2005. Gene expression signatures in neutrophils exposed to glucocorticoid: A new paradigm to help explain "neutrophil dysfunction" in parturient dairy cows. Vet. Immunol. Immunopathol. 105:197-219

4. Chang, X., Mallard, B. A. and Mowat, D. N. 1996. Effects of chromium on health status, blood neutrophil phagocytosis and in vitro lymphocyte blastogenesis of dairy cows. Vet. Immunol. Immunopathol. 52:37-52.

5. Detilleux, J. C., Koehler, K. J., Freeman, A. E., Kehrli, Jr., M. E. and Kelley, D. H. 1994. Immu- nological parameters of periparturient Holstein cattle: genetic variation. J. Dairy Sci. 77:2640-2650.

6. Detilleux, J. C., Kehrli, Jr. M. E., Stabel, J. R., Freeman, A. E. and Kelley, D. H. 1995. Study of immunological dysfunction in periparturient Holstein cattle selected for high and average milk production. Vet. Immunol. Immunopathol. 44:251-267.

7. Kovac, M. and Groeneveld, E. 2003. VCE-5 User's Guide and Reference Manual ver. 5.1.

8. Kulberg, S., Storset, A. K., Heringstad, B. and Larsen, H. J. S. 2002. Reduced levels of total leukocytes and neutrophils in Norwegian cattle selected for decreased mastitis incidence. J. Dairy Sci. 85:3470-3475.

9. SAS User's Guide: Statistics, Version 8.1 Edition. 1999. SAS Inst., Inc., Cary, NC.

10. Smith, B. P. 2002. Large Animal Internal Medicine, $3^{\text {rd }}$, p393. A Mosby Title, Harcourt Health Sciences.

11. 손성기, 허정호, 이주홍, 김충희, 김곤섭, 김종수. 1995. 유방염에 이환된 젖소에 있어서 혈액 동태 학에 관한 연구. 대한수의학회지. 35(3):595-601.

12. 서국현, 이정길, 이채용, 허태영, 이정치, 강석진, 손동수, 안병석, 김남철. 2005. Bovine leukemia virus에 감염된 우리나라 젖소의 말초 혈액내 림 프구 수. 대한수의학회지. 45(2):239-244.

13. 신동백, 박용호, 남향미, 문진산, 주이석, 신종욱. 1996. 건유기 유방염 감염우의 유방내 면역 저하 요인 규명에 관한 연구. I. 유방염 감염우와 정상 우의 말초혈액 및 유즙내 림프구 아집단 분포율 비교. 대한수의학회지. 36(3):635-646.

14. 안병석, 권응기, 서국현, 이현준, 박병기. 2005. 젖소 의 고능력우와 저능력우간의 우유성분 및 혈중대 사물질 특성 비교. 동물자원지. 47(1):11-18.

15. 양일석, 김상근, 김주헌, 김천호, 나승열, 박진홍, 유창준, 윤영원, 이상목, 이장헌, 이호일, 한호재. 1996. 가축생리학. 제 3 판. 광일문화사. $\mathrm{p} 654$.

16. 최유림, 안병석, 서국현, 김준식, 김내수. 1999. 홀 스타인 젖소의 SCS(somatic cell score)에 대한 환 경효과 및 유전모수 추정. 한국축산학회지. 41(2): 141-146.

(접수일자 : 2005. 10. 24. / 채택일자 : 2006. 1. 5.) 